\title{
Effects of kisspeptin on diabetic rat platelets ${ }^{1}$
}

\author{
Zsófia Mezei, Sándor Váczi, Viktória Török, Csaba Stumpf, Rita Ónody, Imre Földesi, and Gyula Szabó
}

\begin{abstract}
Hyperglycemia, hyperlipidemia, and free radicals result in platelet activation and atherogenesis. Kisspeptin (KP) is able to regulate metabolism, hemostasis, and the development of atherosclerosis. We examined whether platelet aggregation of streptozotocin-induced diabetic rats depends on the inducer type and if KP-13 and RF-9 (a kisspeptin receptor modifier) can influence platelet function. We measured the speed and the maximum of aggregation, along with the area under the curve. Serum glucose and calcium levels and urine formation of diabetic animals increased, while the body mass and platelet count decreased. Collagen was the most effective inducer of platelet aggregation. The aggregability of nondiabetic platelets was elevated in the presence of $5 \times 10^{-8} \mathrm{~mol} / \mathrm{L}$ KP-13. This effect was less expressed in diabetic animals. The effectivity of RF-9 was stronger than that of KP-13 in nondiabetic platelets, however it was ineffective in diabetic animals. RF-9 pre-treatment did not change the effects of $5 \times 10^{-8} \mathrm{~mol} / \mathrm{L} \mathrm{KP}-13$ in either animal group. The in vivo activation of diabetic platelets, which may be due to elevated serum calcium, induces thrombocytopenia and may lead to reduced in vitro aggregability. We could not demonstrate the antagonistic effect of RF-9 against KP-13 in isolated platelets.
\end{abstract}

Key words: kisspeptin, platelets, aggregation, RF-9, diabetes, streptozotocin, aggregometry.

Résumé : L'hyperglycémie, l'hyperlipidémie et les radicaux libres mènent à l'activation des plaquettes et à l'athérogénèse. Par ailleurs, la kisspeptine (KP) est en mesure de réguler le métabolisme, l'homéostasie et la formation de l'athérosclérose. Nous avons cherché à observer chez des rats atteints d'un diabète induit par la streptozotocine si l'agrégation plaquettaire dépend du type d'inducteur et si le KP-13 et le RF-9 (un modificateur des récepteurs de la kisspeptine) peuvent influencer la fonction plaquettaire. Nous avons mesuré la vitesse et le maximum de l'agrégation, ainsi que l'aire sous la courbe. Chez les animaux atteints de diabète, les taux sériques de glucose et de calcium, ainsi que la formation d'urine ont augmenté, alors que la masse corporelle et le nombre de plaquettes ont diminué. Le collagène constituait l'inducteur de l'agrégation plaquettaire le plus efficace. Sous KP-13 à $5 \times 10^{-8} \mathrm{~mol} / \mathrm{L}$, l'agrégabilité des plaquettes augmentait en absence de diabète. Cet effet était moins marqué chez les animaux atteints de diabète. Inefficace sur les plaquettes d'animaux atteints de diabète, le RF-9 était plus efficace que le KP-13 en absence de diabète. L'administration préalable de RF-9 n'entraînait des variations des effets du KP-13 à $5 \times 10^{-8}$ mol/L dans aucun des groupes. En présence de diabète, l'activation des plaquettes in vivo, qui pourrait être causée par l'augmentation des taux sériques de calcium, provoque une thrombocytopénie, et pourrait mener à une diminution de l'agrégabilité in vitro. Nous n'avons pas été en mesure de montrer l'effet antagoniste du RF-9 contre le KP-13 dans des plaquettes isolées. [Traduit par la Rédaction]

Mots-clés : kisspeptine, plaquettes, agrégation, RF-9, diabète, streptozotocine, agrégométrie.

\section{Introduction}

Kisspeptins (KPs) are members of the arginine-phenylalanineamide (RF-amide) peptide family. The biologically active forms (KP54, KP-14, KP-13, KP-10), produced by matrix metalloproteinase (Pinilla et al. 2012; Tena-Sempere 2013) can bind to their own receptors (Kirby et al. 2010). One of these is the G protein-coupled receptor (GPR) 54 receptor that by activating the Gq/11, the extracellular signal-regulated protein kinase 1 and 2 (ERK1/2), and the p38 mitogen-activated protein (MAP) kinase signaling pathways (Castaño et al. 2009) might play a role in several intracellular processes. This receptor is antagonized by KP-234 (Roseweir et al. 2009). Another receptor type is the neuropeptide FF (NPFF) receptors (Elhabazi et al. 2013; Lyubimov et al. 2010) that can be coupled to Gi/o proteins leading to the inhibition of adenylate cyclase, resulting in the reduction of cytoplasmic cyclic adenosine monophosphate concentration (Mollereau et al. 2002). RF-9 (1-adamantane
carbonyl-Arg-Phe- $\mathrm{NH}_{2}$ ) is a synthetic peptide that might have a potentially antagonistic effect on KP-13 (Simonin et al. 2006). KPs can participate in the regulation of the reproductive axis (Colledge 2009), the cardiovascular system (Maguire et al. 2011; Mead et al. 2007; Mezei et al. 2015; Sawyer et al. 2011), hemostasis (Qureshi and Kanwal 2011), food intake (Dudek et al. 2016; Hussain et al. 2015; Rao et al. 2013; Tolson et al. 2014; Wahab et al. 2013), and various metabolic pathways (Silvestre et al. 2008; Song et al. 2014).

Kisspeptins (KP-54, KP-13) in a nanomolar concentration can inhibit insulin secretion but only at the physiological concentration of glucose (Vikman and Ahrén 2009). Glucagon may mediate this process, because by stimulating the kisspeptin production of the liver it can suppress the glucose-induced insulin secretion (Song et al. 2014). It is known that impaired KP production inhibits the metabolism and glucose intolerance (Tolson et al. 2014); and obesity (Hussain et al. 2015; Tolson et al. 2014) may develop. Ac-

Received 20 January 2017. Accepted 6 June 2017.

Z. Mezei, S. Váczi, V. Török, C. Stumpf, and G. Szabó. Department of Pathophysiology, University of Szeged, Semmelweis u. 1, 6725 Szeged, Hungary. R. Ónody and I. Földesi. Institute of Laboratory Medicine, University of Szeged, Semmelweis u. 6, 6725 Szeged, Hungary.

Corresponding author: Zsófia Mezei (email: mezeizsofia@gmail.com).

${ }^{1}$ This Article is part of a Special Issue of selected papers from the 3rd European Section Meeting of the International Academy of Cardiovascular Sciences held in Marseille, France, on 1-4 October 2016.

Copyright remains with the author(s) or their institution(s). Permission for reuse (free in most cases) can be obtained from RightsLink. 


\section{Pagination not final (cite DOI) / Pagination provisoire (citer le DOI)}

Can. J. Physiol. Pharmacol. Vol. 00, 0000

cording to Dudek et al. (2016) in the case of diabetic Type 1 rats, very low (e.g., liver and fat) or completely absent KP/GPR54 signaling (e.g., pancreas) may contribute to the impaired regulation of glucose-induced insulin secretion.

Diabetes mellitus is characterized by abnormal carbohydrate, lipid, and protein metabolism. These pathophysiological processes result in hyperglycemia, dyslipidemia, overproduction of reactive oxygen species (ROS), and inflammatory mediators. These changes can induce endothelial dysfunction, atherosclerosis, platelet activation, and pro-thrombotic condition (Hess et al. 2012; Roffi et al. 2011; Randriamboavonjy et al. 2012).

The presence of the KP system was detected also in atherosclerosisprone vessels (Mead et al. 2007) and in the developed edema (Sawyer et al. 2011). The latter was antagonized by cyclooxygenase inhibition. A recent publication reported that KP has an anticoagulant activity that might be mediated through changes in $\mathrm{Ca}$ signaling, consequently leading to a decreased thrombin concentration and platelet number reduction (Qureshi and Kanwal 2011). Platelets may serve as an important link between inflammation, thrombosis, and atherogenesis (Hadi and Suwaidi 2007).

In our earlier experiments, we detected an elevated eicosanoid synthesis of rat platelets in the presence of KP-13 (Mezei et al. 2015).

Therefore in the present study, we aimed to investigate the effect of KP-13 (a biologically active form of KP that binds to both GPR54 and NPFF receptors) and its presumed antagonist, RF-9 peptide, on the platelet aggregation of streptozotocin-induced diabetic rats.

\section{Methods}

\section{Chemicals}

Hirudin blood tubes, disposable multiplate test cells, and inducers of platelet aggregation (ADPItest, ASPItest [arachidonic acid] and COLtest) were purchased from Roche Ltd. (Budapest, Hungary). KP-13 and RF-9 were purchased from Bachem (Bubendorf, Switzerland). Streptozotocin was obtained from Amresco (Solon, Ohio, USA). The original reagents for the determination of hematological parameters were purchased from Sysmex Ltd. (Budapest, Hungary). High-density lipoprotein (HDL) and triglyceride tests were purchased from DiaSys Diagnostic Systems GmbH (Holzheim, Germany), while the other tests for determining the chemical parameters originate from Roche Ltd. (Budapest, Hungary).

\section{Animals}

Animal experiments were performed under a protocol accepted by the Ethical Committee for the Protection of Animals in Research at the University of Szeged, Hungary. All experiments were carried out in accordance with the Guide for the Care and Use of Laboratory Animals published by the US National Institutes of Health.

Streptozotocin (STZ) was used to induce diabetes in WistarKyoto male rats (weighing $210-230 \mathrm{~g}, n=6$ animals). Sixty-five milligrams of STZ was dissolved in $2 \mathrm{~mL}$ of $10 \%(w / v)$ sucrose prepared just before the use. The intraperitoneal injection of STZ $(65 \mathrm{mg} / \mathrm{kg})$ was repeated 3 days later, using the same dose. Nondiabetic rats (weighing 210-230 g, $n=6$ animals) were injected with the solvent as vehicle. After STZ injection, the drinking water of animals was changed for $10 \%(w / v)$ sucrose solution for $24 \mathrm{~h}$ (Furman 2015). The animals were maintained on $12 \mathrm{~h}$ dark/12 $\mathrm{h}$ light cycles in a room at constant temperature $\left(23 \pm 1^{\circ} \mathrm{C}\right)$ with free access to standard laboratory food and water ad libitum.

We monitored serum glucose levels, food and fluid intake, mass and urine volume of the animals during the development of diabetes. Determination of urine volume was carried out by round- the-clock urine collection using a metabolic cage on Day 14 after the second STZ administration. Four weeks later the animals were anesthetized by Euthasol (i.p. $30 \mathrm{mg} / \mathrm{kg}$ ).

\section{Determining the laboratory parameters of rats}

The hematological parameters were determined by Sysmex XE 2100 Automated Hematology System (Sysmex Ltd., Budapest, Hungary). This system utilizes fluorescent flow cytometry and hydrodynamic focusing technologies. White blood cell (leukocyte) differential count and optical platelet count were determined by fluorescent flow cytometry. The platelet (thrombocyte), red blood cell (RBC), hematocrit (HCT) were detected by DC sheath flow. Hemoglobin was detected using Sysmex SULFOLYSER. These measurements were carried out using the original reagents of Sysmex.

The chemical parameters of blood were determined by Hitachi Modular analyzers (Roche Ltd., Budapest, Hungary). The liver function was examined by detecting aspartate aminotransferase (ASAT) and alanine aminotransferase (ALAT) using a UV test and ALP by colorimetric assay in the serum. Kidney function was analyzed by measuring serum creatinine (kinetic colorimetric assay) and serum urea by kinetic UV assay. The serum glucose levels were measured by enzymatic colorimetric assay. The serum lipid parameters were determined as serum HDL cholesterol (timeconsuming precipitation method) and serum triglycerides (colorimetric enzymatic test). Serum low-density lipoprotein (LDL) cholesterol was calculated using the Friedewald formula as follows (all measurements are in $\mathrm{mmol} / \mathrm{L}$ ): LDL cholesterol $=$ Total cholesterol - HDL cholesterol - (Total triglyceride $\div 2.19$ ). HDL and triglyceride tests were purchased from DiaSys Diagnostic Systems $\mathrm{GmbH}$ (Holzheim, Germany), while the other tests originate from Roche Ltd. (Budapest, Hungary). Results of these assays were compared to the age- and gender-dependent normal values of rat laboratory parameters, published by Charles River Laboratories ${ }^{2}$.

\section{Multiple electrode aggregometry (MEA)}

The Multiplate test principle is based on Cardinal and Flower's impedance aggregometry method (introduced in 1980). Unlike in systems applied earlier, the Multiplate analyzer provides a disposable test cuvette featuring a duplicate sensor. The principle of MEA is that the electric impedance occurring between the silvercoated platinum electrodes merging into the blood sample positively correlates with the rate of platelet aggregation. The SI unit of impedance is $\mathrm{Ohm}(\Omega)$. The device, however, uses "arbitrary units (AU)" ( $1 \mathrm{AU}$ is equal to approximately $8 \Omega$ ). The patented twin sensor technology enables optimal results and an internal quality control, since 2 parallel measurements are carried out at the same time. Testing whole blood eliminates the need for time-consuming sample preparation, while the natural physiological milieu for platelet function is well-maintained. Only a small quantity $(300 \mu \mathrm{L})$ of whole blood is required per test. The aggregometer is capable of performing 5 measurements simultaneously.

\section{The interpretation of the aggregation curve}

The aggregation curve is the quantitative display of the reaction, and it represents the rate of aggregation (AU) plotted against time. The curve is characterized by the following parameters: area under the curve (AUC) in units (U) providing the most precise assessment of the whole reaction; speed in units (AU/min) representing the slope of the curve (speed of aggregation, SA), which gives information about the initial kinetics of the reaction (primary aggregation); peak of the curve in units (AU) showing the maximal aggregation (MA) during the whole reaction.

\footnotetext{
${ }^{2}$ http://www.criver.com/files/pdfs/rms/cd/rm_rm_r_clinical_parameters_cd_rat_06.aspx.
} 


\section{Pagination not final (cite DOI) / Pagination provisoire (citer le DOI)}

\section{The inducers of the reaction}

The manufacturer of the aggregometer provides an array of inducers that provoked platelet aggregation. Using the different inducers, the pathways of platelet activation can be examined separately, providing a useful tool in diagnostics regarding platelet disorders and drug effects. In our current study, we used 3 inducers: arachidonic acid, ADP, and collagen. The inducers are marketed in a lyophilized form. Before usage, $1 \mathrm{~mL}$ of ion-free water had to be added carefully, avoiding foam generation. After $10 \mathrm{~min}$ standing at room temperature, the solution was ready to use.

\section{Performing a measurement}

\section{Preparation of blood samples}

Whole blood was collected from the abdominal aorta of anesthetized (Euthasol $30 \mathrm{mg} / \mathrm{kg}$ body mass i.p.) rats with a thick needle and drawn into a plastic tube, containing $15 \mu \mathrm{g} / \mathrm{mL}$ hirudin (Tóth et al. 2006). The specimens were gently mixed by hand with end-over-end inversion for 3 to 6 times and transported to the laboratory at room temperature. The aggregometric examination was carried out within $1.5 \mathrm{~h}$ after the collection of blood (Sweeney et al. 1989).

The platelet count of specimens was determined and standardized. All of the aggregometric cuvettes contained the same number of platelets $\left(250-350 \times 10^{9}\right.$ platelets/L). When the platelet count of the sample was higher, it was diluted by its own plateletpoor plasma. If the sample contained fewer platelets, we applied a greater amount of blood and a lesser amount of $0.9 \% \mathrm{NaCl}$ solution in the aggregometric cuvette. The platelet count was also measured after the aggregation to detect potential thrombocytolysis.

The total volume of a test cuvette is $620 \mu \mathrm{L}$. According to the original measurement protocol of the device, the solution contains the following: $300 \mu \mathrm{L}$ whole blood, $300 \mu \mathrm{L}$ 0.9\% sodium chloride $(\mathrm{NaCl})$ solution, and $20 \mu \mathrm{L}$ inducer. The investigated peptides are not included in this protocol, hence we had to modify the composition of the solution. We used the aggregometer in a semiautomatic mode. The basic principle was the following: with every addition of $20 \mu \mathrm{L}$ peptide (diluted in physiological saline solution) we reduced the amount of $0.9 \% \mathrm{NaCl}$ solution with $20 \mu \mathrm{L}$, thus keeping the final volume of the solution constant $(620 \mu \mathrm{L})$. The inducers in the $620 \mu \mathrm{L}$ solution were the following: $\mathrm{ADP}(6.5 \mathrm{mmol} / \mathrm{L})$ arachidonic acid $(0.5 \mathrm{mmol} / \mathrm{L})$ and collagen $(3.2 \mathrm{mg} / \mathrm{mL})$.

\section{Examining the effect of inducers on rat platelets}

At first we assessed the control effect of inducers. $300 \mu \mathrm{L}$ whole blood and $300 \mu \mathrm{L} 0.9 \% \mathrm{NaCl}$ solution were added into the test cuvette. After $3 \mathrm{~min}$ of incubation outside the aggregometer, the cuvette was attached to the device and another $3 \mathrm{~min}$ of incubation was performed. Then the aggregation reaction was initiated by administering $20 \mu \mathrm{L}$ of inducer (ADP, arachidonic acid, or collagen). The measurement was performed with all 3 inducers in each animal.

\section{Examining the effect of peptides on rat platelets}

KP-13 (the presumed agonist) and RF-9 (the presumed antagonists) were investigated. The following peptide concentrations were applied: $0,1.25 \times 10^{-8}, 2.5 \times 10^{-8}, 5 \times 10^{-8}, 10 \times 10^{-8} \mathrm{~mol} / \mathrm{L}$.

We examined the sole effect of each peptide. In these experimental arrangements $20 \mu \mathrm{L}$ peptide was added to $300 \mu \mathrm{L}$ blood and $280 \mu \mathrm{L}$ saline. After $3 \mathrm{~min}$ of incubation outside the aggregometer, the cuvette was attached to the device and another $3 \mathrm{~min}$ of incubation was performed. Then the aggregation reaction was initiated by administering $20 \mu \mathrm{L}$ of inducer (ADP, arachidonic acid, or collagen). The measurement was performed with all 3 inducers for every animal's blood samples.

To verify the antagonistic activity of RF-9, the sample had to be pre-incubated with one of the aforementioned peptides before the addition of KP-13. Twenty $\mu \mathrm{L}$ of RF-9 was added to $300 \mu \mathrm{L}$ blood
Table 1. Physical parameters of diabetic and nondiabetic rats.

\begin{tabular}{lll}
\hline & Nondiabetic & \\
& rats & Diabetic rats \\
\hline Mean water intake (mL/week) & $263.8(10.1)$ & $938.0^{*}(49.9)$ \\
Mean food intake $(\mathrm{g} /$ week) & $202.2(3.2)$ & $224.0^{*}(5.2)$ \\
Final body mass $(\mathrm{g})$ & $475.0(6.2)$ & $283.6^{*}(20.5)$ \\
Mean urine volume (mL/day) & $122.2(3.4)$ & $175.4^{*}(5.9)$ \\
\hline
\end{tabular}

Note: Data are mean \pm (SE) of 6 samples/animals. Body mass was measured before anesthesia. Urine volume was measured on Day 14 after the second STZ administration and was expressed in $\mathrm{mL} /$ day. STZ, streptozotocin. ${ }^{*} p<0.05$ diabetic vs. nondiabetic rats.

diluted with $260 \mu \mathrm{L}$ saline. After $3 \mathrm{~min}$ of incubation the test cell was attached to the aggregometer and KP-13 was added. The reaction was initiated after another $3 \mathrm{~min}$ of incubation by administering $20 \mu \mathrm{L}$ of inducer (ADP, arachidonic acid, or collagen). The measurement was performed with all 3 inducers on every animal's blood samples.

\section{Statistical analysis}

The results are expressed as means \pm SE. The significance of the differences between the platelet aggregation of the peptidetreated and untreated platelets in diabetic or nondiabetic rats was determined by one-way analysis of variance (ANOVA), followed by Tukey's multiple comparison post hoc test. This statistical analysis was also carried out at the same peptide concentration between the diabetic and nondiabetic groups. A difference at a level $p<0.05$ was considered statistically significant. The statistical analysis was performed by SPSS version 22.0 (IBM Corp. Released 2013. IBM SPSS Statistics for Windows, Version 22.0. Armonk, NY: IBM Corp.).

\section{Results}

The development of STZ-induced diabetes in male rats was confirmed by a significant elevation in water drinking (from $263.8 \pm$ $10.1 \mathrm{~mL} /$ week to $938 \pm 49.9 \mathrm{~mL} /$ week) and in food intake (from $202.2 \pm 3.2$ to $224 \pm 5.2 \mathrm{~g} /$ week) (Table 1). Parallel with this, we detected a $40.2 \%$ reduction in body weight and $43.4 \%$ elevation in urine formation in diabetic animals compared to the nondiabetic control rats (Table 1).

The development of diabetes mellitus was also verified by the significant increase in serum glucose level, from $9.5 \pm 0.45 \mathrm{mmol} / \mathrm{L}$ to $25.4 \pm 0.88 \mathrm{mmol} / \mathrm{L}$ (Table 2). This serum glucose level was about 2.5 times higher than the highest normal parameter published by Charles River Laboratories. Serum calcium (3.2 \pm 0.08 vs. $2.8 \pm$ $0.02 \mathrm{mmol} / \mathrm{L}), \operatorname{ALAT}(83.6 \pm 8.58$ vs. $38.7 \pm 2.17 \mathrm{U} / \mathrm{L})$, ALP $(265 \pm 23.54$ vs. $77.7 \pm 4.03 \mathrm{U} / \mathrm{L})$ and urea $(11.2 \pm 0.95$ vs. $6.9 \pm 0.27 \mathrm{mmol} / \mathrm{L})$ levels of diabetic rats were also significantly elevated, compared to those of nondiabetic animals. These parameters were higher than the normal values published by Charles River Laboratories, while the serum triglyceride was elevated $(1.5 \pm 0.27$ vs. $0.9 \pm 0.1 \mathrm{mmol} / \mathrm{L})$ only when we compared it to the values of nondiabetic rats (Table 2).

Both the RBC $\left(7.4 \pm 0.2\right.$ vs. $\left.8.1 \pm 0.11 \times 10^{12} / \mathrm{L}\right)$ and the platelet count $\left(292.8 \pm 22.53\right.$ vs. $\left.367.3 \pm 10.92 \times 10^{9} / \mathrm{L}\right)$ were significantly lower in the diabetic rats, compared to the nondiabetic animals, and these numbers are lower than the normal physiological values (Table 3). Parallel with this, we detected lower hemoglobin $(129.4 \pm 2.8$ vs. $141.2 \pm 2.24 \mathrm{~g} / \mathrm{L})$ and mean corpuscular hemoglobin concentration $(346.8 \pm 3.81$ vs. $369.3 \pm 2.33 \mathrm{~g} / \mathrm{L})$ concentrations in the diabetic group. Hematocrit was not different from the control animals, while the plateletcrit (the mass of platelets) was reduced in the diabetic rats $(0.2 \pm 0.02$ vs. $0.3 \pm 0.01 \%)$, compared to the nondiabetic animals (Table 3 ).

We compared the aggregatory effects of different inducers (ADP, arachidonic acid, collagen) in nondiabetic (Table 4A) and diabetic 


\section{Pagination not final (cite DOI) / Pagination provisoire (citer le DOI)}

Table 2. Chemical laboratory parameters of serum in diabetic and nondiabetic rats.

\begin{tabular}{|c|c|c|}
\hline & $\begin{array}{l}\text { Nondiabetic } \\
\text { rats }\end{array}$ & Diabetic rats \\
\hline Glucose (mmol/L) & $9.5(0.45)$ & $25.4^{*}(0.88)$ \\
\hline $\mathrm{CHOL}(\mathrm{mmol} / \mathrm{L})$ & $2.1(0.23)$ & $2.5(0.24)$ \\
\hline TG (mmol/L) & $0.9(0$ & $1.5^{*}(0.27)$ \\
\hline HDL (mmol/L) & $1.2(0$ & $1.5(0.16)$ \\
\hline $\mathrm{LDL}(\mathrm{mmol} / \mathrm{L})$ & $0.6(0.10)$ & $0.6(0.34)$ \\
\hline ASAT (U/L) & $63.5(5$ & $87.0(13.38)$ \\
\hline ALAT (U/L) & $38.7(2.17)$ & $83.6^{*}(8.58)$ \\
\hline $\operatorname{ALP}(\mathrm{U} / \mathrm{L})$ & 77.7 (4.03) & $265.0^{*}(23.54)$ \\
\hline Urea $(\mathrm{mmol} / \mathrm{L})$ & $6.9(0.27)$ & $11.2^{*}(0.95)$ \\
\hline Creatinine $(\mu \mathrm{mol} / \mathrm{L})$ & $26.2(2.88)$ & $25.6(0.98)$ \\
\hline Calcium $(\mathrm{mmol} / \mathrm{L})$ & $2.8(0.02)$ & $3.2^{*}(0.08)$ \\
\hline \multicolumn{3}{|c|}{$\begin{array}{l}\text { Note: Data are mean } \pm \text { (SE) of } 6 \text { samples/animals. The pa- } \\
\text { rameters show the serum glucose, in mmol/L, lipids (serum } \\
\text { cholesterol, triglyceride, HDL, LDL in mmol/L), liver enzymes } \\
\text { (serum ASAT, ALAT, ALP in U/L), kidney function (serum urea } \\
\text { in mmol/L, creatinine in } \mu \text { mol/L) and the serum calcium level } \\
\text { in mmol/L). CHOL, total cholesterol; TG, triglyceride; HDL, } \\
\text { high-density lipoprotein; LDL, low-density lipoprotein; ASAT, } \\
\text { aspartate aminotransferase; ALAT, alanine aminotransferase; } \\
\text { ALP, alkaline phosphatase. }{ }^{*} p<0.05 \text { diabetic vs. nondiabetic } \\
\text { rats. }\end{array}$} \\
\hline
\end{tabular}

Table 3. Hematological laboratory parameters of serum in diabetic and nondiabetic rats.

\begin{tabular}{lcr}
\hline & \multicolumn{2}{l}{ Nondiabetic } \\
& \multicolumn{1}{c}{ rats } & Diabetic rats \\
\hline WBC $\left(10^{9} / \mathrm{L}\right)$ & $4.0(0.36)$ & $2.8(0.44)$ \\
RBC $\left(10^{12} / \mathrm{L}\right)$ & $8.1(0.11)$ & $7.4^{*}(0.20)$ \\
HGB $(\mathrm{g} / \mathrm{L})$ & $141.2(2.24)$ & $129.4^{*}(2.80)$ \\
HCT $(\mathrm{L} / \mathrm{L})$ & $0.4(0.01)$ & $0.4(0.01)$ \\
MCV (fL) & $47.3(0.70)$ & $50.8^{*}(1.04)$ \\
MCH (pg) & $17.5(0.21)$ & $17.6(0.18)$ \\
MCHC (g/L) & $369.3(2.33)$ & $346.8^{*}(3.81)$ \\
PLT $\left(10^{9} / \mathrm{L}\right)$ & $367.3(10.92)$ & $292.8^{*}(22.53)$ \\
RDW-SD $(\%)$ & $23.0(0.54)$ & $28.7^{*}(1.24)$ \\
PDW (fL) & $7.8(0.28)$ & $7.2(0.22)$ \\
PCT (\%) & $0.3(0.01)$ & $0.2^{*}(0.02)$ \\
\hline
\end{tabular}

Note: Data are mean $\pm(\mathrm{SE})$ of 6 samples/animals. WBC, white blood cell (leukocytes); RBC, red blood cell; HGB, hemoglobin; HCT, hematocrit; MCV, mean corpuscular volume; $\mathrm{MCH}$, mean corpuscular hemoglobin; MCHC, mean corpuscular hemoglobin concentration; PLT, platelet (thrombocyte); RDW-SD, red blood cell distribution width standard deviation; PDW, platelet distribution width; PCT, plateletcrit (thrombocrit) reflects the mass of platelets. It is a calculated value. Laser-based optical analyzers calculated plateletcrit as follows: Plateletcrit $(\%)=(\mathrm{MPV} \times$ PLT count $) \div 1000 .{ }^{*} p<0.05$ diabetic vs. nondiabetic rats.

Table 4. Comparison of different inducers on diabetic and nondiabetic rat platelet aggregation.

\begin{tabular}{lllr}
\hline & ADP & $\begin{array}{l}\text { Arachidonic } \\
\text { acid }\end{array}$ & Collagen \\
\hline Nondiabetic rats & & & \\
Area under the curve (U) & $49.0(4.2)$ & $53.0(4.6)$ & $56.9(3.1)$ \\
Maximal aggregation (AU) & $75.5(5.5)$ & $80.2(6.0)$ & $78.3(4.0)$ \\
Speed of aggregation (AU/min) & $16.3(1.8)$ & $18.3(2.0)$ & $23.5^{*}(1.3)$ \\
Diabetic rats & & & \\
Area under the curve (U) & $49.6(4.6)$ & $48.0(4.6)$ & $57.9(3.6)$ \\
Maximal aggregation (AU) & $73.5(6.0)$ & $70.1(6.0)$ & $78.2(4.7)$ \\
Speed of aggregation (AU/min) & $18.5(2.0)$ & $18.6(2.0)$ & $22.7(1.6)$ \\
\hline
\end{tabular}

Note: Data are means \pm (SE) of 6 samples/animals. U, unit; AU, arbitrary unit. ${ }^{*} p<0.05$ collagen vs. ADP.
(Table 4B) rat platelets. We measured 3 characteristic parameters of the aggregation curves (AUC, MA, SA). All these parameters were found to be the highest in case of collagen-induced platelet aggregation in both animal groups (Table 4).

Therefore we examined the effect of KP-13 and RF-9 on the collagen-induced aggregation of nondiabetic and diabetic rat platelets. KP-13 $\left(5 \times 10^{-8} \mathrm{~mol} / \mathrm{L}\right)$ induced significant increase in nondiabetic rat platelet aggregation compared to the peptide-free controls. This effect is represented by an increase in AUC (from $56.9 \pm 3.26$ to $69.73 \pm 3.27 \mathrm{U}$ ), an elevation in MA (from $78.33 \pm 4.2$ to $97.39 \pm 4.19 \mathrm{AU}$ ), and in SA (from $23.49 \pm 1.67$ to $28.21 \pm 1.68 \mathrm{AU}$ / min) (Fig. 1A). Although we increased the peptide concentration further, no augmentation of platelet aggregation was observed (i.e., we obtained a plateau-shaped dose-response curve). Since in the presence of KP-13 we detected significant elevation (by 22\%) only in case of MA, an increased platelet aggregability of diabetic rats could not be sufficiently demonstrated in vitro (Fig. 1B). The speed of the collagen-induced aggregation of nondiabetic platelets was significantly increased by $5 \times 10^{-8} \mathrm{KP}-13(28.21 \pm 1.68 \mathrm{AU} /$ min, Fig. 1A) compared to diabetic rats $(22.8 \pm 1.76 \mathrm{AU} / \mathrm{min}$, Fig. $1 \mathrm{~B})$.

When we tested RF-9, a presumed KP antagonist, we detected significant augmentation of platelet aggregation in nondiabetic rats (Fig. 2A) already at a concentration of $2.5 \times 10^{-8} \mathrm{~mol} / \mathrm{L} \mathrm{com}-$ pared to the peptide-free control, while the same concentration of KP-13 (Fig. 1A) did not induce significant elevation. At this concentration, RF-9 increased the AUC, MA, and SA (by $29 \%, 28.9 \%$, and $28.6 \%$, respectively) compared to the peptide-untreated samples of nondiabetic rats (Fig. 2A), while the same concentration of KP-13 induced only a moderate elevation in these parameters (AUC and MA by $16.6 \%$, SA by $14.5 \%$, Fig. 1A). The dose-response curve of RF-9 was the same as the one induced by KP-13. The aggregation of diabetic platelets was not modified significantly by any of the RF-9 concentrations applied (Fig. 2B). On the other hand, the AUC (75.6 \pm 4.8 vs. $58.8 \pm 4.9 \mathrm{U})$ and the MA (107.72 \pm 6.23 vs. $86.78 \pm$ $6.22 \mathrm{AU}$ ) significantly increased in nondiabetic platelets (Fig. 2A), compared to diabetic thrombocytes (Fig. 2B) in the presence of $10 \times 10^{-8} \mathrm{~mol} / \mathrm{L}$ RF-9.

The platelet aggregation increasing effect of $5 \times 10^{-8} \mathrm{~mol} / \mathrm{L} \mathrm{KP}-13$ was not prevented by the pre-treatment with various concentrations of RF-9 (Fig. 3). The aggregability of nondiabetic platelets was significantly higher than that of diabetic animals already at $2.5 \times$ $10^{-8} \mathrm{~mol} / \mathrm{L}$ concentration of RF-9 as a pre-treatment and at $5 \times$ $10^{-8} \mathrm{~mol} / \mathrm{L}$ concentration of KP-13 as treatment (AUC 70.4 $\pm 4.84 \mathrm{vs}$. $51 \pm 5.4$ U, MA $99 \pm 6.2$ vs $77.18 \pm 6.96$ AU, SA $27 \pm 2.49$ vs. $19.55 \pm$ $2.78 \mathrm{AU} / \mathrm{min}$ ). This significant difference between the 2 animal groups can be explained by the fact that the platelet aggregation of nondiabetic animals was significantly elevated (Fig. 3A), while that of diabetic rats was moderately reduced (Fig. 3B).

\section{Discussion}

It is well known that the molecular structure of streptozotocin contains glucose and $\mathrm{N}$-methyl- $\mathrm{N}$-nitrosourea groups, both playing a role in the induction of diabetes mellitus in different animals (e.g., in rats) (Elsner et al. 2000). The glucose binding to the glucose transporter-2 (GLUT-2) receptor of pancreatic $\beta$ cells helps the intake of STZ by these cells. The $N$-methyl- $N$-nitrosourea group induces DNA methylation (Szkudelski 2012), alkylation (Friederich et al. 2009) and oxidation (Gul et al. 2002) leading to the apoptosis of pancreatic $\beta$ cells. Many physical parameters (polyuria, polydipsia, polyphagia, and losing of body mass) and laboratory data (elevation of glucose level, dyslipidemia), which were detected in our experiments, verify the generation of diabetes in rats by streptozotocin. The GLUT-2 transporter can be found not only on the pancreatic $\beta$ cells but also on the hepatocytes and renal tubular epithelial cells (Eleazu et al. 2013; Valentovic et al. 2006). Therefore, the detected abnormal functions of the liver (elevated ALAT, ALP, triglyceride) and kidney (urine, creatinine) are assumed to be 
Fig. 1. Effect of kisspeptin-13 (KP-13) on the collagen-induced aggregation of rat platelets. Data are mean \pm SE of 6 samples/animals. U, unit; AU, arbitrary unit. ${ }^{*} p<0.05 \mathrm{KP}-13$ vs. peptide-free sample.

\section{A. Non-diabetic rats}

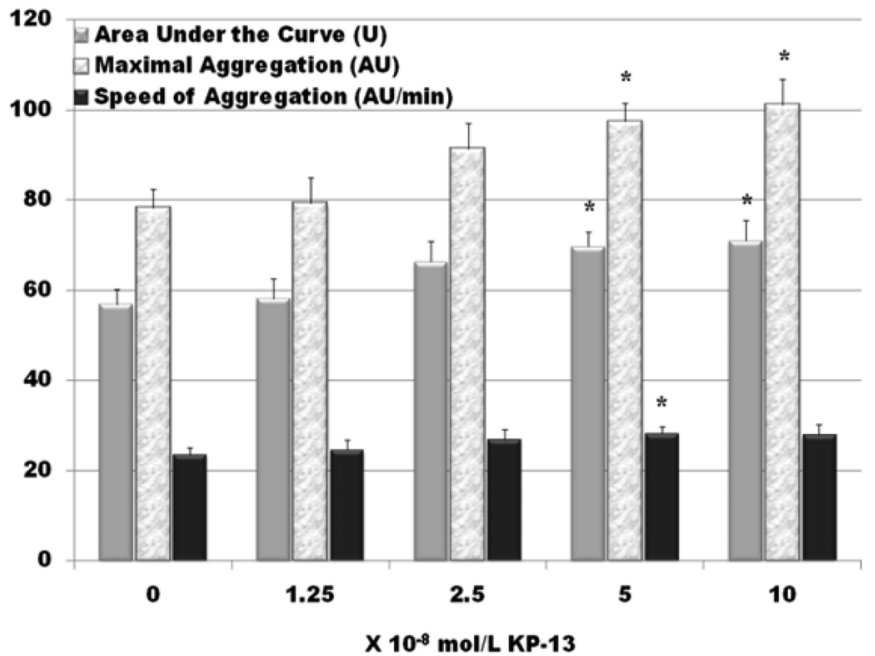

\section{B. Diabetic rats}

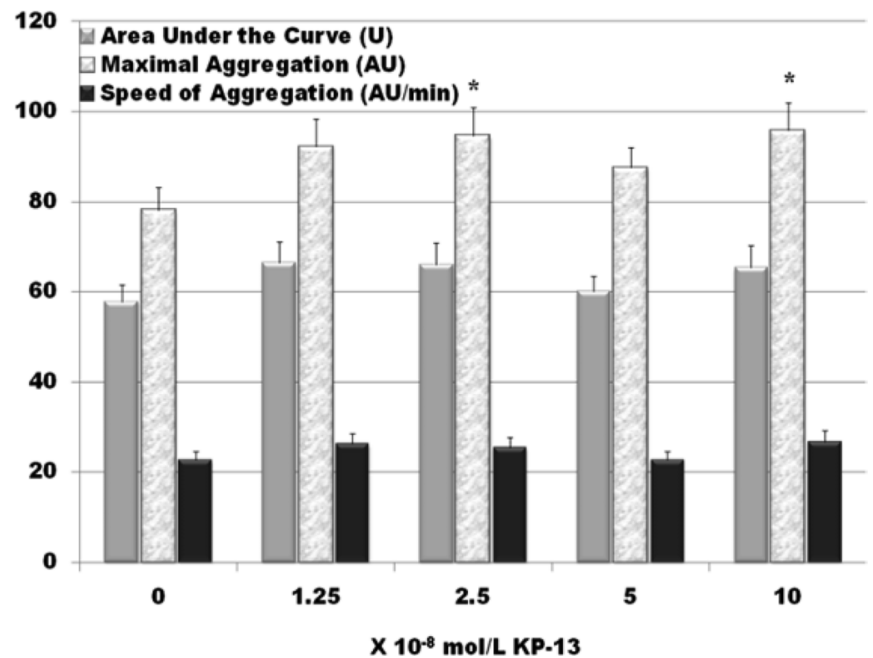

Fig. 2. Effect of arginine phenylalanine (RF)-9 on the collagen-induced aggregation of rat platelets. Data are mean \pm SE of 6 samples/animals. U, unit; AU, arbitrary unit. ${ }^{*} p<0.05$ RF-9 vs. peptide-free sample.

\section{A. Non-diabetic rats}

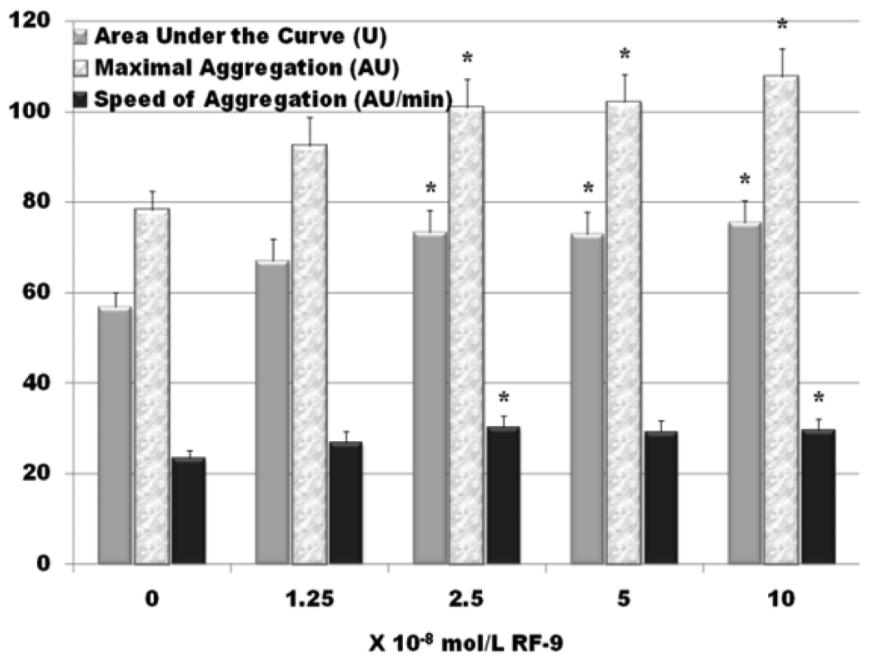

induced by the toxic effect of STZ. Toxic effects of STZ and diabetic condition together lead to the development of dyslipidemia. The detected portal congestion might be the consequence of liver failure caused by STZ. We presume that malabsorption caused by portal congestion together with STZ-induced reduction of erythropoietin production by the kidney can induce anemic condition and thrombocytopenia that we detected in the present experiments.

It has already been published that the hyperreactivity of platelets is an important complication during diabetes mellitus (Ferreiro and Angiolillo 2011; Randriamboavonjy et al. 2012; Roffi et al. 2011). The hyperreactivity of thrombocytes may be also induced indirectly. In this case the diabetic endothelial dysfunction (releasing platelet activator factors and expressing adhesion receptors) can indirectly result in platelet activation (Paneni et al. 2013; Yeom et al. 2016). Hyperglycemia, hypoinsulinemia, dyslipidemia, and oxidative stress, during diabetic condition - alone or

\section{B. Diabetic rats}

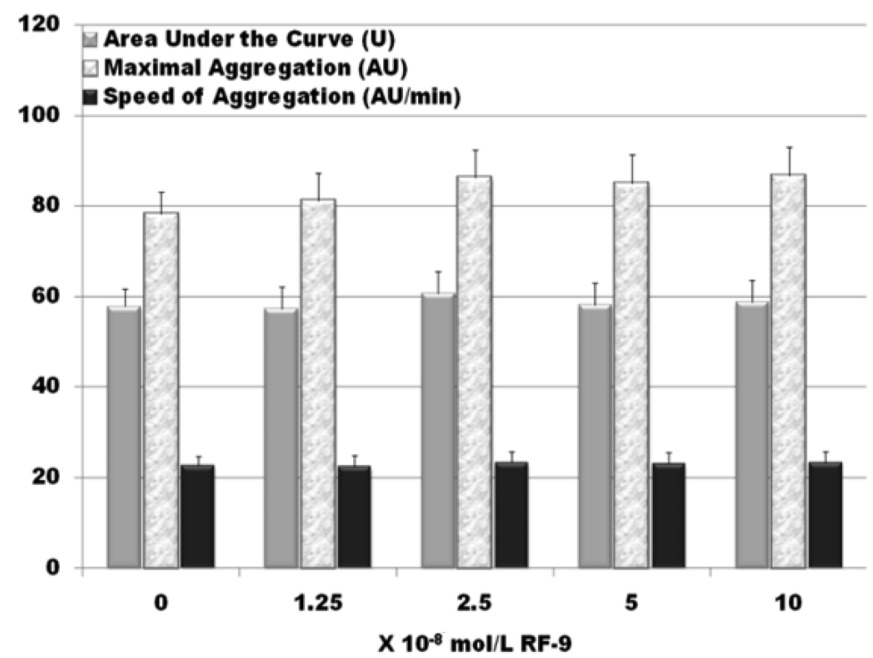

in synergism - can directly activate the platelets (Ferreiro and Angiolillo 2011). Hyperglycemia, by stimulating the receptor expression of platelets (Kotzailias et al. 2009), elevating the intracellular calcium ion level (Liu et al. 2008), producing ROS (Tang et al. 2014), and activating the p38/MAP kinase pathway (Tang et al. 2011) leads to platelet adhesion, aggregation, and secretion. An elevated serum glucose level also leads to the formation of advanced glycation end-products, and it can stimulate platelet receptor expression and secretion (Gawlowski et al. 2009). Moreover, it has already been demonstrated that the low insulin level also results in platelet activation (Ferreira et al. 2006).

Dyslipidemia (elevated LDL, decreased HDL) can stimulate thromboxane synthesis due to the increased intracellular calcium level (Pedreño et al. 2001; Siewiera et al. 2016). The apoptosis of thrombocytes by oxidative stress has already been reported by Leytin (2012). These processes, alone or together, might play a role in the in vivo activation of circulating blood platelets, which may 
Fig. 3. Effect of $5 \times 10^{-8} \mathrm{~mol} / \mathrm{L}$ kisspeptin-13 (KP-13) on the collagen-induced aggregation of arginine phenylalanine (RF)-9 pre-treated rat platelets. Data are mean \pm SE of 6 samples/animals. U, unit; AU, arbitrary unit. ${ }^{*} p<0.05$ RF-9 vs. peptide-free sample.

\section{A. Non-diabetic rats}

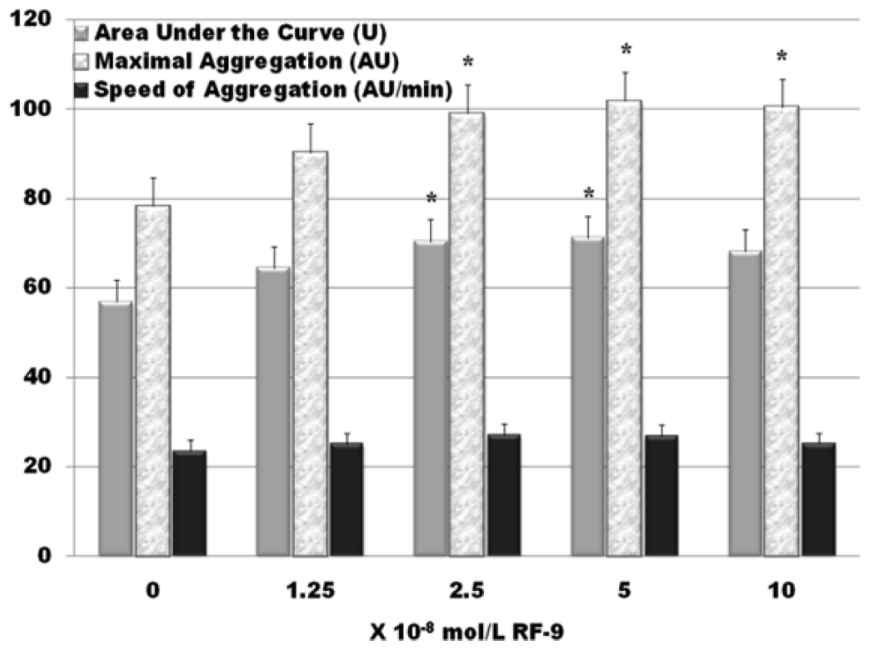

explain the platelet number reduction in diabetic rats in the present experiments. Yeom et al. (2016) also reported the elevated adhesion of platelets and the reduction of platelet number in diabetic rats in a time-dependent manner.

We detected that collagen was the most effective inducer for the ex vivo examination of platelet aggregation, however we could not find significant difference between the diabetic and nondiabetic platelet aggregability. The application of this inducer is supported by the fact that collagen plays an important role in those pathological conditions in which endothelial dysfunction participates. The similar ex vivo reaction of the diabetic and nondiabetic platelets might be explained by the period of time elapsing after the induction of diabetes. This is supported by the fact that the effect of diabetes on platelet function (e.g., thromboxane synthesis and adhesion) is also time-dependent (Siewiera et al. 2016; Yeom et al. 2016).

In addition to its several other effects, KP can prolong the bleeding time and reduce the number of platelets in rats. This was detected when KP-13 was applied intraperitoneally in vivo (Qureshi and Kanwal 2011). In our earlier experiments we detected an enhancement of thromboxane (a potent vasoconstrictor and platelet aggregator) synthesis of rat platelets in the presence of KP-13 (Mezei et al. 2015). In our present study, we observed that KP-13 enhanced the aggregation of nondiabetic platelets in a dosedependent manner, in the presence of collagen as inducer. On the other hand, this effect was only moderate in diabetic thrombocytes. It has already been reported that KP (binding to the G-protein coupled receptor and activating several intracellular processes) can induce the elevation of intracellular calcium ion (Kotani et al. 2001; Cvetković et al. 2013). We may suggest that the KP-13-induced increase of nondiabetic platelet aggregation is mediated by elevated intracellular calcium ion level, because it participates in the activation of thromboxane synthesis, the degranulation and the receptor expression of platelets. These processes alone and together can support and accelerate the aggregation process (Li et al. 2010). We may think that the reduced ex vivo aggregability of diabetic platelets to KP-13 is explained by the in vivo activation of diabetic platelets, which is demonstrated by the degranulation of thrombocytes, the glycation of receptors, and the alteration of membrane fluidity (Randriamboavonjy et al. 2012). On the other hand, it has already been reported that the glycation of cyclooxygenase enzyme (Angiolillo and Suryadevara 2009) and diabetic dyslipidemia (Watala et al. 2005; Kim et al.

\section{B. Diabetic rats}

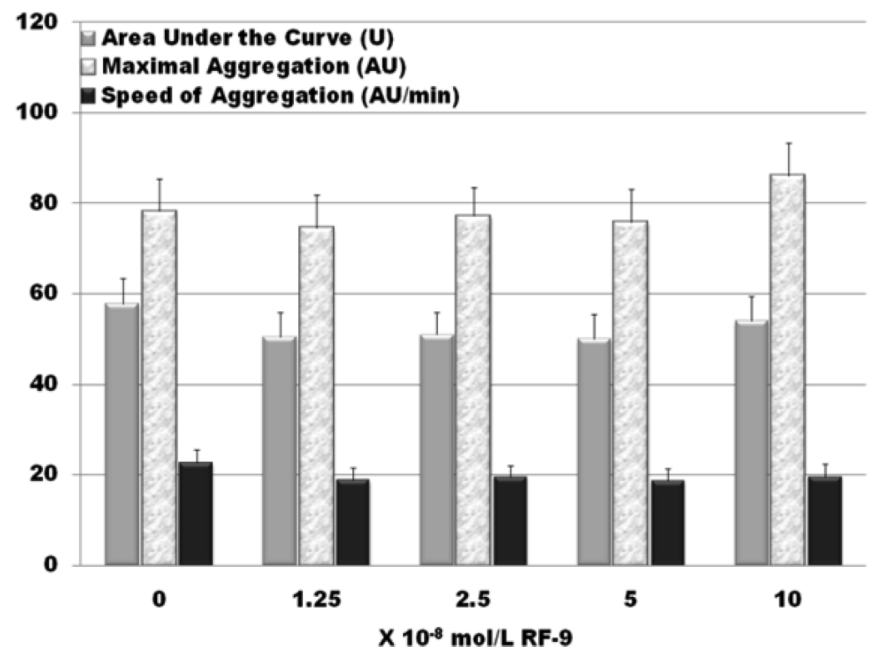

2014) play a role in the development of aspirin resistance. Simonin et al. (2006) reported that RF-9 binding to the NPFF-receptor, type 2 (NPFF2R) KP receptor might have a potentially antagonistic effect on KP-13. In this case, RF-9 coupled to Gi/o protein should have resulted in elevated cytoplasmic cyclic adenosine monophosphate and reduced intracellular calcium ion level, and as a result, reduced platelet aggregation. In the present experiment, the application of RF-9, even at a lower peptide concentration than KP-13, induced hyperaggregability of nondiabetic platelets. We assume that RF-9 is likely to have an effect not only on NPFF2 but also on another receptor. This is also supported by Maletínská et al. (2013), reporting that RF-9 is a partial agonist of KP receptor, and Min et al. (2014), discussing RF-9 as a KP receptor agonist. In our experiment using a pre-treatment with RF-9, we could not verify its antagonistic effect on KP, moreover we demonstrated a synergy with KP-13. Our results can be supported by the data published by Kim et al. (2014), reporting that RF-9, the presumed antagonists of NPFF1R, is in fact the agonist of both NPFF1R and the KP receptor (KISS1R). The reason that the RF-9 pre-treatment induced even stronger platelet activation (compared to the case when only KP was used), can be found in that the elevation of the ic. $\mathrm{Ca}^{2+}$ level induced by RF-9 may augment the expression of the platelet receptors (e.g., KISS1R) (Min et al. 2014; Babwah et al. 2012). Exploring the mechanism of these diverging receptorial effects requires further investigations.

In conclusion, it has been demonstrated that KP-13 was able to enhance ex vivo collagen-induced aggregability of nondiabetic rat platelets in a dose-dependent manner, in which the enhancement of thromboxane synthesis (as our team has already published) may also play a role (Mezei et al. 2015). Streptozocin-induced experimental diabetes in rats did not induce significant change in the collagen-induced aggregability of platelets in vitro. This may be explained by the long lasting in vivo activation of platelets during the development of diabetes and their structural and functional impairment. Under these experimental conditions RF-9 did not prove to be an antagonist of KP-13, moreover it potentiated platelet aggregation.

\section{Acknowledgements}

This work was supported by grants from Hungarian Brain Research Program - Grant No. KTIA_13_NAP-A-III/8 and Roche Ltd., Budapest, Hungary. 


\section{References}

Angiolillo, D.J., and Suryadevara, S. 2009. Aspirin and clopidogrel: efficacy and resistance in diabetes mellitus. Best Pract. Res. Clin. Endocrinol. Metab. 23(3): 375-388. doi:10.1016/j.beem.2008.12.001. PMID:19520310.

Babwah, A.V., Pampillo, M., Min, L., Kaiser, U.B., and Bhattacharya, M. 2012. Single-cell analyses reveal that KISS1R-expressing cells undergo sustained kisspeptin-induced signaling that is dependent upon an influx of extracellular $\mathrm{Ca}^{2+}$. Endocrinology, 153(12): 5875-5887. doi:10.1210/en.2012-1747. PMID: 23070548.

Castaño, J.P., Martínez-Fuentes, A.J., Gutiérrez-Pascual, E., Vaudry, H., Tena-Sempere, M., and Malagón, M.M. 2009. Intracellular signaling pathways activated by kisspeptins through GPR54: do multiple signals underlie function diversity? Peptides, 30(1): 10-15. doi:10.1016/j.peptides.2008.07.025. PMID:18775460

Colledge, W.H. 2009. Kisspeptins and GnRH neuronal signalling. Trends Endocrinol. Metab. 20(3): 115-121. doi:10.1016/j.tem.2008.10.005. PMID:19097915.

Cvetković, D., Babwah, A.V., and Bhattacharya, M. 2013. Kisspeptin/KISS1R system in breast cancer. J. Cancer, 4(8): 653-661. doi:10.7150/jca.7626. PMID: 24155777.

Dudek, M., Kołodziejski, P.A., Pruszyńska-Oszmałek, E., Sassek, M., Ziarniak, K., Nowak, K.W., and Sliwowska, J.H. 2016. Effects of high-fat diet-induced obesity and diabetes on Kiss1 and GPR54 expression in the hypothalamicpituitary-gonadal (HPG) axis and peripheral organs (fat, pancreas and liver) in male rats. Neuropeptides, 56: 41-49. doi:10.1016/j.npep.2016.01.005. PMID: 26853724.

Eleazu, C.O., Iroaganachi, M., and Eleazu, K.C. 2013. Ameliorative potentials of cocoyam (Colocasia esculenta L.) and unripe plantain (Musa paradisiaca L.) on the relative tissue weights of streptozotocin-induced diabetic rats. J. Diabetes Res. 2013: 160964. doi:10.1155/2013/160964. PMID:23971053.

Elhabazi, K., Humbert, J.-P., Bertin, I., Schmitt, M., Bihel, F., Bourguignon, J.-J., et al. 2013. Endogenous mammalian RF-amide peptides, including PrRP, kisspeptin and 26RFa, modulate nociception and morphine analgesia via NPFF receptors. Neuropharmacology, 75: 164-171. doi:10.1016/j.neuropharm.2013. 07.012. PMID:23911743.

Elsner, M., Guldbakke, B., Tiedge, M., Munday, R., and Lenzen, S. 2000. Relative importance of transport and alkylation for pancreatic beta-cell toxicity of streptozotocin. Diabetologia, 43(12): 1528-1533. doi:10.1007/s001250051564. PMID:11151762.

Ferreira, I.A., Mocking, A.I.M., Feijge, M.A.H., Gorter, G., van Haeften, T.W., Heemskerk, J.W., and Akkerman, J.-W.N. 2006. Platelet inhibition by insulin is absent in type 2 diabetes mellitus. Arterioscler. Thromb. Vasc. Biol. 26(2): 417-422. doi:10.1161/01.ATV.0000199519.37089.a0. PMID:16339499.

Ferreiro, J.L., and Angiolillo, D.J. 2011. Diabetes and antiplatelet therapy in acute coronary syndrome. Circulation. 123(7): 798-813. doi:10.1161/CIRCULATIONAHA. 109.913376. PMID:21343595.

Friederich, M., Hansell, P., and Palm, F. 2009. Diabetes, oxidative stress, nitric oxide and mitochondria function. Curr. Diabetes Rev. 5(2): 120-144. doi:10. 2174/157339909788166800. PMID:19442097.

Furman, B.L. 2015. Streptozotocin-induced diabetic models in mice and rats. Curr. Protoc. Pharmacol. 70: 5.47.1-20. doi:10.1002/0471141755.ph0547s70. PMID:26331889.

Gawlowski, T., Stratmann, B., Ruetter, R., Buenting, C.E., Menart, B., Weiss, J., et al. 2009. Advanced glycation end products strongly activate platelets. Eur. J. Nutr. 48(8): 475-481. doi:10.1007/s00394-009-0038-6. PMID:19633966.

Gul, M., Laaksonen, D.E., Atalay, M., Vider, L., and Hänninen, O. 2002. Effects of endurance training on tissue glutathione homeostasis and lipid peroxidation in streptozotocin-induced diabetic rats. Scand. J. Med. Sci. Sports, 12(3): 163170. doi:10.1034/j.1600-0838.2002.120307.x. PMID:12135449.

Hadi, H.A., and Suwaidi, J.A. 2007. Endothelial dysfunction in diabetes mellitus. Vasc. Health Risk Manag. 3(6): 853-876.

Hess, H., Marx, N., and Lehrke, M. 2012. Cardiovascular disease and diabetes: the vulnerable patient. Eur. Heart J. Suppl. 14(Suppl. B): B4-B13. doi:10.1093/ eurheartj/sus002.

Hussain, M.A., Song, W.-J., and Wolfe, A. 2015. There is kisspeptin - And then there is kisspeptin. Trends Endocrinol. Metab. 26(10): 564-572. doi:10.1016/j. tem.2015.07.008. PMID:26412157.

Kim, J.D., Park, C.-Y., Ahn, K.J., Cho, J.H., Choi, K.M., Kang, J.G., et al. 2014. Non-HDL cholesterol is an independent risk factor for aspirin resistance in obese patients with type 2 diabetes. Atherosclerosis, 234(1): 146-151. doi:10. 1016/j.atherosclerosis.2014.01.015. PMID:24657383.

Kirby, H.R., Maguire, J.J., Colledge, W.H., and Davenport, A.P. 2010. International Union of Basic and Clinical Pharmacology. LXXVII. Kisspeptin receptor nomenclature, distribution, and function. Pharmacol. Rev. 62(4): 565-578. doi: 10.1124/pr.110.002774. PMID:21079036.

Kotani, M., Detheux, M., Vandenbogaerde, A., Communi, D., Vanderwinden, J.-M., Le Poul, E., et al. 2001. The metastasis suppressor gene KiSS-1 encodes kisspeptins, the natural ligands of the orphan G protein-coupled receptor GPR54. J. Biol. Chem. 276(37): 34631-34636. doi:10.1074/jbc.M104847200. PMID: 11457843.

Kotzailias, N., Graninger, M., Knechtelsdorfer, M., and Jilma, B. 2009. Acute effects of hyperglycaemia on plasma concentration of soluble P-selectin and von Willebrand factor in healthy volunteers - a prospective randomised double blind controlled study. Thromb. Res. 123(3): 452-459. doi:10.1016/j. thromres.2008.06.015. PMID:18707755.

Leytin, V. 2012. Apoptosis in the anucleate platelet. Blood Rev. 26(2): 51-63. doi:10.1016/j.blre.2011.10.002. PMID:2055392.

Li, Z., Delaney, M.K., O’Brien, K.A., and Du, X. 2010. Signaling during platelet adhesion and activation. Arterioscler. Thromb. Vasc. Biol. 30(12): 2341-2349. doi:10.1161/ATVBAHA.110.207522. PMID:21071698.

Liu, D., Maier, A., Scholze, A., Rauch, U., Boltzen, U., Zhao, Z., Zhu, Z., et al. 2008. High glucose enhances transient receptor potential channel canonical type 6-dependent calcium influx in human platelets via phosphatidylinositol 3-kinase-dependent pathway. Arterioscler. Thromb. Vasc. Biol. 28(4): 746751. doi:10.1161/ATVBAHA.108.162222. PMID:18258814.

Lyubimov, Y., Engstrom, M., Wurster, S., Savola, J.-M., Korpi, E.R., and Panula, P. 2010. Human kisspeptins activate neuropeptide FF2 receptor. Neuroscience, 170(1): 117-122. doi:10.1016/j.neuroscience.2010.06.058. PMID:20600636.

Maguire, J.J., Kirby, H.R., Mead, E.J., Kuc, R.E., d'Anglemont de Tassigny, X., Colledge, W.H., and Davenport, A.F. 2011. Inotropic action of the puberty hormone kisspeptin in rat, mouse and human: cardiovascular distribution and characteristics of the kisspeptin receptor. PLoS One, 6(11): e27601. doi:10. 1371/journal.pone.0027601. PMID:22132116.

Maletínská, L., Tichá, A., Nagelová, V., Spolcová, A., Blechová, M., Elbert, T., and Zelezná, B. 2013. Neuropeptide FF analog RF9 is not an antagonist of NPFF receptor and decreases food intake in mice after its central and peripheral administration. Brain Res. 1498: 33-40. doi:10.1016/j.brainres.2012.12.037. PMID:23291266.

Mead, E.J., Maguire, J.J., Kuc, R.E., and Davenport, A.P. 2007. Kisspeptins are novel potent vasoconstrictors in humans, with a discrete localization of their receptor, G protein-coupled receptor 54, to atherosclerosis-prone vessels. Endocrinology, 148(1): 140-147. doi:10.1210/en.2006-0818. PMID:17023533.

Mezei, Z., Zamani-Forooshani, O., Csabafi, K., Szikszai, B., Papp, E., Ónodi, Á., et al. 2015. The effect of kisspeptin on the regulation of vascular tone. Can. J. Physiol. Pharmacol. 93(9): 787-791. doi:10.1139/cjpp-2015-0013. PMID:26242914.

Min, L., Soltis, K., Reis, A.C.S., Xu, S., Kuohung, W., Jain, M., et al. 2014. Dynamic kisspeptin receptor trafficking modulates kisspeptin-mediated calcium signaling. Mol. Endocrinol. 28(1): 16-27. doi:10.1210/me.2013-1165. PMID:24295737.

Mollereau, C., Mazarguil, H., Marcus, D., Quelven, I., Kotani, M., Lannoy, V., et al. 2002. Pharmacological characterization of human $\mathrm{NPFF}_{1}$ and $\mathrm{NPFF}_{2}$ receptors expressed in $\mathrm{CHO}$ cells by using NPY $\mathrm{Y}_{1}$ receptor antagonists. Eur. J. Pharmacol. 451(3): 245-256. doi:10.1016/S0014-2999(02)02224-0. PMID:12242085.

Paneni, F., Beckman, J.A., Creager, M.A., and Cosentino, F. 2013. Diabetes and vascular disease: pathophysiology, clinical consequences, and medical therapy: part I. Eur. Heart J. 34(31): 2436-2443. doi:10.1093/eurheartj/eht149. PMID: 23641007.

Pedreño, J., Hurt-Camejo, E., Wiklund, O., Badimón, L., and Masana, L. 2001. Low-density lipoprotein (LDL) binds to a G-protein coupled receptor in human platelets. Evidence that the proaggregatory effect induced by LDL is modulated by down-regulation of binding sites and desensitization of its mediated signaling. Atherosclerosis, 155(1): 99-112. doi:10.1016/S0021-9150(00) 00545-1. PMID:11223431.

Pinilla, L., Aguilar, E., Dieguez, C., Millar, R.P., and Tena-Sempere, M. 2012. Kisspeptins and reproduction: physiological roles and regulatory mechanisms. Physiol. Rev. 92(3): 1235-1316. doi:10.1152/physrev.00037.2010. PMID: 22811428.

Qureshi, I.Z., and Kanwal, S. 2011. Novel role of puberty onset protein kisspeptin as an anticoagulation peptide. Blood Coagul. Fibrinolysis, 22(1): 40-49. doi: 10.1097/MBC.0b013e328340e6a7. PMID:21042204.

Randriamboavonjy, V., Isaak, J., Elgheznawy, A., Pistrosch, F., Frömel, T., Yin, X., et al. 2012. Calpain inhibition stabilizes the platelet proteome and reactivity in diabetes. Blood, 120(2): 415-423. doi:10.1182/blood-2011-12-399980. PMID: 22665935

Rao, P.M., Kelly, D.M., and Jones, T.H. 2013. Testosterone and insulin resistance in the metabolic syndrome and T2DM in men. Nat. Rev. Endocrinol. 9(8): 479-493. doi:10.1038/nrendo.2013.122. PMID:23797822.

Roffi, M., Angiolillo, D.J., and Kappetein, A.P. 2011. Current concepts on coronary revascularization in diabetic patients. Eur. Heart J. 32(22): 2748-2757. doi:10. 1093/eurheartj/ehr305. PMID:21893486.

Roseweir, A.K., Kauffman, A.S., Smith, J.T., Guerriero, K.A., Morgan, K., Pielecka-Fortuna, J., et al. 2009. Discovery of potent kisspeptin antagonists delineate physiological mechanisms of gonadotropin regulation. J. Neurosci. 29(12): 3920-3929. doi:10.1523/JNEUROSCI.5740-08.2009. PMID:19321788.

Sawyer, I., Smillie, S.-J., Bodkin, J.V., Fernandes, E., O’Byrne, K.T., and Brain, S.D. 2011. The vasoactive potential of kisspeptin-10 in the peripheral vasculature. PLoS One, 6(2): e14671. doi:10.1371/journal.pone.0014671. PMID:21347414.

Siewiera, K., Kassassir, H., Talar, M., Wieteska, L., and Watala, C. 2016. Long-term untreated streptozotocin-diabetes leads to increased expression and elevated activity of prostaglandin H2 synthase in blood platelets. Platelets, 27(3): 203211. doi:10.3109/09537104.2015.1075492. PMID:26325148.

Silvestre, R.A., Egido, E.M., Hernández, R., and Marco, J. 2008. Kisspeptin-13 inhibits insulin secretion without affecting glucagon or somatostatin release: study in the perfused rat pancreas. J. Endocrinol. 196(2): 283-290. doi:10.1677/JOE-07-0454. PMID:18252951.

Simonin, F., Schmitt, M., Laulin, J.-P., Laboureyras, E., Jhamandas, J.H., MacTavish, D., et al. 2006. RF9, a potent and selective neuropeptide FF receptor 


\section{Pagination not final (cite DOI) / Pagination provisoire (citer le DOI)}

antagonist, prevents opioid-induced tolerance associated with hyperalgesia. Proc. Natl. Acad. Sci. U.S.A. 103(2): 466-471. doi:10.1073/pnas.0502090103. PMID:16407169.

Song, W.-J., Mondal, P., Wolfe, A., Alonso, L.C., Stamateris, R., Ong, B.W.T., et al. 2014. Glucagon regulates hepatic kisspeptin to impair insulin secretion. Cell Metab. 19(4): 667-681. doi:10.1016/j.cmet.2014.03.005. PMID:24703698.

Sweeney, J.D., Hoernig, L.A., Michnik, A., and Fitzpatrick, J.E. 1989. Whole blood aggregometry. Influence of sample collection and delay in study performance on test results. Am. J. Clin. Pathol. 92(5): 676-679. doi:10.1093/ajcp/92. 5.676. PMID:2816822.

Szkudelski, T. 2012. Streptozotocin-nicotinamide-induced diabetes in the rat. Characteristics of the experimental model. Exp. Biol. Med. (Maywood), 237(5): 481-490. doi:10.1258/ebm.2012.011372. PMID:22619373.

Tang, W.H., Stitham, J., Gleim, S., Di Febbo, C., Porreca, E., Fava, C., et al. 2011. Glucose and collagen regulate human platelet activity through aldose reductase induction of thromboxane. J. Clin. Invest. 121(11): 4462-4476. doi:10.1172/ JCI59291. PMID:22005299.

Tang, W.H., Stitham, J., Jin, Y., Liu, R., Lee, S.H., Du, J., et al. 2014. Aldose reductase-mediated phosphorylation of p53 leads to mitochondrial dysfunction and damage in diabetic platelets. Circulation, 129(15): 1598-1609. doi:10. 1161/CIRCULATIONAHA.113.005224. PMID:24474649.

Tena-Sempere, M. 2013. Kisspeptins. In Handbook of Biologically Active Peptides. Edited by J.A. Kastin. Academic Press, Boston, pp. 819-827.

Tolson, K.P., Garcia, C., Yen, S., Simonds, S., Stefanidis, A., Lawrence, A., et al. 2014. Impaired kisspeptin signaling decreases metabolism and promotes glu- cose intolerance and obesity. J. Clin. Invest. 124(7): 3075-3079. doi:10.1172/ JCI71075. PMID:24937427.

Tóth, O., Calatzis, A., Penz, S., Losonczy, H., and Siess, W. 2006. Multiple electrode aggregometry: a new device to measure platelet aggregation in whole blood. Thromb. Haemost. 96(6): 781-788. doi:10.1160/TH06-05-0242. PMID: 17139373.

Valentovic, M.A., Alejandro, N., Betts Carpenter, A., Brown, P.I., and Ramos, K. 2006. Streptozotocin (STZ) diabetes enhances benzo(alpha)pyrene induced renal injury in Sprague Dawley rats. Toxicol. Lett. 164(3): 214-220. doi:10.1016/ j.toxlet.2005.12.009. PMID:16460892.

Vikman, J., and Ahrén, B. 2009. Inhibitory effect of kisspeptins on insulin secretion from isolated mouse islets. Diabetes Obes. Metab. 11(Suppl. 4): 197-201. doi:10.1111/j.1463-1326.2009.01116.x. PMID:19817802.

Wahab, F., Atika, B., and Shahab, M. 2013. Kisspeptin as a link between metabolism and reproduction: evidences from rodent and primate studies. Metabolism, 62(7): 898-910. doi:10.1016/j.metabol.2013.01.015. PMID:23414722.

Watala, C., Pluta, J., Golanski, J., Rozalski, M., Czyz, M., Trojanowski, Z., and Drzewoski, J. 2005. Increased protein glycation in diabetes mellitus is associated with decreased aspirin-mediated protein acetylation and reduced sensitivity of blood platelets to aspirin. J. Mol. Med. (Berl.), 83(2): 148-158. doi:10.1007/s00109-004-0600-x. PMID:15723265.

Yeom, E., Byeon, H., and Lee, S.J. 2016. Effect of diabetic duration on hemorheological properties and platelet aggregation in streptozotocin-induced diabetic rats. Sci. Rep. 6: 21913. doi:10.1038/srep21913. PMID:26898237. 